
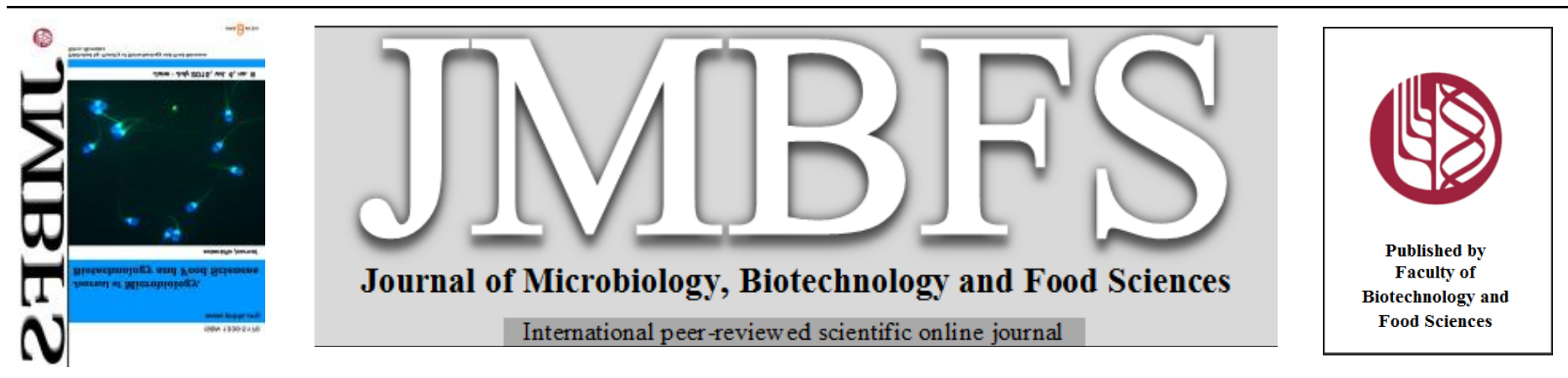

\title{
POTENTIAL ANTIMICROBIAL ACTIVITY OF BACTERIAL ENDOPHYTES ISOLATED FROM FLACOURTIA JANGOMAS (LOUR.)RAEUSCH, A LESS EXPLORED MEDICINAL PLANT
}

\author{
Swati Shukla, Gaurav Naik, Sarad Kumar Mishra* \\ Address(es): Dr. Sarad Kumar Mishra, \\ D.D.U. Gorakhpur University, Gorakhpur, Department of Biotechnology, U.P., 273009, India, phone: +919450682713
}

*Corresponding author: saradmishra5@gmail.com

doi: 10.15414/jmbfs.2015.4.6.473-477

\section{ARTICLE INFO}

Received 14. 1. 2015

Revised 13. 2. 2015

Accepted 27. 2. 2015

Published 1. 6. 2015

Regular article open $\partial$ access

\begin{abstract}
Recently focus on research has increased on natural products, new and useful compounds like antibiotics, chemotherapeutic agents, agrochemicals that are low toxic, highly effective and minor environment impact. The study was designed to screen the antibacterial potential of bacterial endophytes isolated from different medicinal plants against Gram positive and Gram negative human pathogenic bacteria. Endophytes were isolated by using standard protocols from three medicinal plants. Primary screening and secondary screening were done by perpendicular streaking and agar well diffusion method respectively to check antimicrobial property of endophytes. Antibiotic susceptibility test of pathogenic bacteria was determined by disc diffusion method against a number of antibiotics. After screening, it was found that $\mathrm{FjR}_{1}$ and $\mathrm{FjF}_{2}$ isolated from Flacourtia jangomas (Lour.) Raeusch showed potential antimicrobial activity against both Gram positive and Gram negative pathogenic bacteria. The present study shows that $F$. jangomas is a good source for bacterial endophytes which can be promising source for production of effective antimicrobial compound with pharmacological importance.
\end{abstract}

Keywords: Flacourtia jangomas (Lour.) Raeusch, Endophytes, Pathogenic bacteria, Gram positive bacteria, Gram negative bacteria

\section{INTRODUCTION}

Medicinal plants are the important part of the human society to combat diseases. In developing country like India, medicinal plants are the important source for people to fight against various diseases and disorders. Various plant species are explored by ethnic societies for their medicinal applications. Various parts of plant are traditionally used by ethnic societies for their preliminary health treatment like fruit, leaves, root, stem bark in the form of infusions, decoctions, concoctions (Khan et al., 2012 ). Recently, focus on plant research has increased all over the world for the production of secondary metabolites. In search for new drugs or secondary metabolites, microbial endophytes are promising source for production of effective and unique metabolites with potential pharmacological importance (Aly et al., 2010). Endophytic bacteria are those bacteria which invade and colonize within the living plant tissues, without causing any apparent harmful effects (Bacon and White, 2000; Wilson, 1995). In order to colonize the plant and for competition from other microorganisms they produce antimicrobial compounds and many enzymes (Lima et al., 2005). A variety of antibiotics (Pleban et al., 1997), enzymes, anticancerous (Stierle et al., 1993), anti-inflammatory (Trischman et al., 1994), antifungal (Korzybsky et al., 1978) and biological control (Hallmann et al., 1997) agents have been isolated from endophytic microorganisms. Approximately, 30,000 plant species are present on earth (Strobel and Daisy, 2003), but only a few plant associated endophytic microorganisms have been studied thoroughly. Therefore, there is a need to explore or discover novel and interesting endophytic microorganisms capable to producing natural products and bioactive secondary metabolites (Srobel $\boldsymbol{e t}$ al., 2004). Several important attributes and medicinal properties of plants may be due to endophytes residing in it. Numerous studies have also demonstrated that endophytes synthesize bioactive compounds which help to promote plant growth and increase resistance in plant against their pathogens (Rosenblueth and Martines-Romero, 2006; Ryan et al., 2008).

Flacourtia jangomas, Catharenthus roseus and Embilica officinalis are well known medicinal plants. Ether extract and alcoholic extract of fruit of Embilica officinalis has been reported to have strong antimicrobial property while fruit extract of $F$. jangomas showed good activity against Pseudomonas aeruginosa, Klebsiella pneumonia and Escherichia coli (Srivastava et al., 2010).
The aim of this study was to isolate endophytic bacteria from different parts (stem, root, fruit, and leaves) of these medicinal plants and to screen their antimicrobial activity against pathogenic microorganisms.

\section{MATERIAL AND METHODS}

\section{Collection of plant sample}

For isolation of endophytic bacteria, three medicinal plants were choosen viz: Flacourtia jangomas, Embilica officinalis, and Catharenthus roseus from the Botanical Garden of D.D.U. Gorakhpur University. Leaves, roots, stems, fruits and bark were carefully cut out, tagged and stored in plastic bags at $4^{\circ} \mathrm{C}$. Within 5-6 hours, these plant materials were used for the isolation of endophytes.

\section{Isolation of endophytic bacteria}

The collected plants were first briefly washed under running tap water and the stems, leaves were cut into small pieces. These small pieces were rinsed in sterile distilled water and after that surface sterilization was performed by treating first with $70 \%$ ethanol for $30 \mathrm{sec}$ and then with $0.1 \%$ mercuric chloride solution for 2 min. The disinfected parts of plants were rinsed again with distilled water and drained. After that, they were cut longitudinally with a sterile scalpel, and after removing the outer layer of plant part inner exposed parts of plant were placed on autoclaved nutrient agar (Hung and Annapurna, 2004). Surface disinfected intact plant parts were also placed on nutrient agar as control. All plates were incubated at $30^{\circ} \mathrm{C}$ for several days. Bacterial colonies around the cut pieces were selected as endophytic bacteria.

\section{Screening of antibacterial activity}

Clinical pathogens gram positive (Staphylococcus aureus, Staphylococcus aureus MTCC-737) and gram negative bacteria (Escherichia coli, Pseudomonas sp., Proteus vulgaris, Klebsiella sp., E. coli MTCC-443) were used to evaluate the antimicrobial activity of endophytic bacteria. All pathogenic bacteria (E. coli, Pseudomonas sp., Proteus vulgaris, Klebsiella sp., S. aureus) were obtained from B.R.D. Medical College Gorakhpur, India. 
Screening of endophytic bacteria was performed in two steps i.e. primary screening and secondary screening.

\section{Primary Screening}

Determination of antibacterial activity through primary screening was done by perpendicular streak method (Oskay et al., 2004). Nutrient agar plates were prepared in which isolated endophytic bacteria were streaked in the centre and these plates were incubated at $37^{\circ} \mathrm{C}$ for two days. Later the pathogens (Staphylococcus aureus, Staphylococcus aureus MTCC-737, Escherischia coli, Pseudomonas sp., Proteus vulgaris, Klebsiella sp., E. coli MTCC-443) were single streaked perpendicular to endophytic strain without touching it and again incubated at $37^{\circ} \mathrm{C}$ for 24 hours. Antagonism was measured by measuring the inhibition zone.

\section{Secondary Screening}

Secondary screening of $\mathrm{FjR}_{1}$ and $\mathrm{FjF}_{2}$ endophytic bacterial strains was done by agar well diffusion method (Pandey et al., 2004) using different solvents (Chloroform, Hexane, Ethyl acetate, Xylene, Butanol). $100 \mu 1$ of pathogenic microorganisms in nutrient broth (absorbance 0.1 at $660 \mathrm{~nm}$ ) was spread on Nutrient Agar (NA) plates. A well of $8 \mathrm{~mm}$ diameter was bored with the help of sterile cork borer and $150 \mu 1$ of solvent extract was loaded into first well. These plates were incubated at $37^{\circ} \mathrm{C}$ for $24 \mathrm{~h}$.

\section{Physiological Characterization}

Isolated endophytic bacterial strains $\left(\mathrm{FjR}_{1}\right.$ and $\left.\mathrm{FjF}_{2}\right)$ were grown in nutrient broth at different sodium chloride concentration $(2 \%, 4 \%, 6 \%, 8 \%, 10 \%$ and $12 \%)$ different sodium azide concentration $(0.001 \%, 0.01 \%, 0.05 \%, 0.10 \%, 0.15 \%$, $0.2 \%$ and $0.5 \%)$ and different phenol concentration $(0.001 \% 0.001 \%, 0.01 \%$, $0.05 \%, 0.10 \%, 0.2 \%$ and $0.5 \%$ ). All flasks were incubated at $37^{\circ} \mathrm{C}$ for 24 hours and results were recorded (Singh $\boldsymbol{e t}$ al., 2013)

\section{Morphological and Biochemical Characterization}

Standard morphological and biochemical tests were performed for the identification of endophytic bacteria. They were characterized by gram staining, endospore formation and biochemical tests like citrate utilization, oxidase, nitrate reduction, gelatin liquefaction, starch hydrolysis, catalase, methyl red (MR). Carbohydrate fermentation tests were also carried out (Cappucino and
Sherman, 1998) using sucrose, fructose, lactose, xylose, mannitol, raffinose. They were identified according to Bergey's Manual of Systemic Bacteriology.

\section{Antibiotic susceptibility test of pathogenic bacteria}

The antibiotic sensitivity of pathogenic bacteria was determined by disc diffusion method against a number of antibiotics (Norfloxacin-10 $\mu$ g.disk ${ }^{-1}$, Aztreonam-30 $\mu$ g.disk ${ }^{-1}$, Cefotaxime-30 $\mu$ g.disk ${ }^{-1}$, Ceftriaxone-30 $\mu$ g.disk ${ }^{-1}$, Nalidixic acid-30 $\mu \mathrm{g} . \mathrm{disk}^{-1}$, Fluconazole-300 $\mu$ g.disk ${ }^{-1}$, Cefuroxime- $30 \mu \mathrm{g} \cdot$ disk $^{-1}$, Gentamycin-10 $\mu$ g.disk ${ }^{-1}$, Amikacin-30 $\mu$ g.disk ${ }^{-1}$, Ciprofloxacin-5 $\mu$ g.disk ${ }^{-1}$, Ofloxacin-5 $\mu$ g.disk , Ceftazidime-30 $\mu$ g.disk ${ }^{-1}$, Cefixime-5 $\mu$ g.disk ${ }^{-1}$, Cefdinir-5 $\mu$ g.disk ${ }^{-1}$ and Ampicilline-10 $\mu$ g.disk ${ }^{-1}$ ) with different concentrations. Antibiotics disc was purchased from Span Diagnostic Ltd. (Gujarat, India). The antibacterial assay was performed on Mueller Hinton Agar by disc diffusion method (ELMehalawy et al., 2005).

\section{RESULTS AND DISCUSSION}

\section{Isolation of endophytic bacteria}

Total nineteen endophytic bacteria were isolated through surface sterilization method (Hung and Annapurna, 2004) from different parts of three medicinal plants viz: Flacourtia jangomas, Embilica officinalis, Catharanthus roseus. Out of nineteen, thirteen endophytic bacteria were isolated from different parts of $F$. jangomas ( 2 from root $\&$ fruit each, 4 from leaf $\&$ stem each and 1 from bark). Out of four bacterial endophytes isolated from Embilica officinalis, 3 were from its leaf and 1 from its stem. Two endophytes ( 1 from stem \& 1 from leaf) were isolated from Catharanthus roseus plant as shown in Table 1.

\section{Screening of antimicrobial property}

Antimicrobial activity of endophytic bacteria was studied against Gram positive (Staphylococcus aureus) and Gram negative (Escherichia coli, Pseudomonas sp., Proteus vulgaris, Klebsiella sp.) bacteria. Out of all above, only two endophytic bacterial isolates $\left(\mathrm{FjR}_{1}\right.$ and $\mathrm{FjF}_{2}$ were isolated from root and fruit of $F$. jangomas respectively, inhibited all Gram positive and Gram negative pathogenic bacteria used in the study, while $\mathrm{FjR}_{2}, \mathrm{EoL}_{1}$ and $\mathrm{EoL}_{2}$ were able to inhibit only $S$. aureus Rest other isolated endophytes showed mixed results as shown in Table 1 and Figure 1. Benny et al. (2011) also performed the screening of fruit extract of $F$. inermis against multidrug resistant bacteria and reported that acetonic extract of fruit has strong antimicrobial activity (Shibumon and Benny, 2010).

Table 1 Antimicrobial activity of isolated strain

\begin{tabular}{|c|c|c|c|c|c|c|c|c|}
\hline $\begin{array}{l}\text { Bacterial } \\
\text { isolates }\end{array}$ & Plants \& Parts & S. aureus & $\begin{array}{l}\text { Pseudomonas } \\
\text { sp. }\end{array}$ & $\begin{array}{l}\text { Proteus } \\
\text { vulgaris }\end{array}$ & E. coli & $\begin{array}{l}\text { Klebsiella } \\
\text { sp. }\end{array}$ & $\begin{array}{c}\text { S. aureus } \\
\text { MTCC } 737\end{array}$ & $\begin{array}{c}E . \text { coli } \\
\text { MTCC } 443\end{array}$ \\
\hline $\mathrm{FjR}_{1}$ & F. jangomas (root) & + & + & + & + & + & + & + \\
\hline $\mathrm{FjR}_{2}$ & F. jangomas (root) & + & - & - & - & - & - & - \\
\hline $\mathrm{FjL}_{1}$ & F. jangomas (leaf) & + & + & - & - & + & + & - \\
\hline $\mathrm{FjL}_{2}$ & F. jangomas (leaf) & - & - & - & - & - & + & - \\
\hline $\mathrm{FjL}_{3}$ & F. jangomas (leaf) & - & - & - & + & - & - & + \\
\hline $\mathrm{FjL}_{4}$ & F. jangomas (leaf) & - & - & - & - & - & + & - \\
\hline $\mathrm{FjS}_{1}$ & $F$. jangomas (stem) & + & + & + & - & + & - & - \\
\hline $\mathrm{FjS}_{2}$ & $F$. jangomas (stem) & - & + & + & - & - & - & + \\
\hline $\mathrm{FjS}_{3}$ & $F$. jangomas (stem) & - & + & - & + & - & + & + \\
\hline $\mathrm{FjS}_{4}$ & $F$. jangomas (stem) & + & + & - & + & - & - & - \\
\hline $\mathrm{FjB}$ & $F$. jangomas (bark) & + & + & + & + & + & - & - \\
\hline $\mathrm{FjF}_{1}$ & $F$. jangomas (fruit) & - & - & - & - & - & - & - \\
\hline $\mathrm{FjF}_{2}$ & $F$. jangomas (fruit) & + & + & + & + & + & + & + \\
\hline $\mathrm{CrS}$ & C. roseus (stem) & + & + & - & + & + & $\mathrm{NC}$ & $\mathrm{NC}$ \\
\hline $\mathrm{CrL}$ & C. roseus(leaf) & + & + & - & - & - & $\mathrm{NC}$ & $\mathrm{NC}$ \\
\hline $\mathrm{EoL}_{1}$ & E. officinalis (leaf) & + & - & - & - & - & $\mathrm{NC}$ & $\mathrm{NC}$ \\
\hline $\mathrm{EoL}_{2}$ & E. officinalis (leaf) & + & - & - & - & - & $\mathrm{NC}$ & $\mathrm{NC}$ \\
\hline $\mathrm{EoL}_{3}$ & E. officinalis (leaf) & + & + & - & + & + & $\mathrm{NC}$ & $\mathrm{NC}$ \\
\hline EoS & E. officinalis (stem) & - & - & + & + & - & $\mathrm{NC}$ & $\mathrm{NC}$ \\
\hline
\end{tabular}




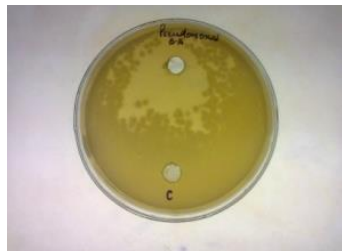

(a)

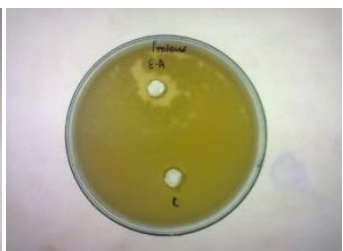

(b)

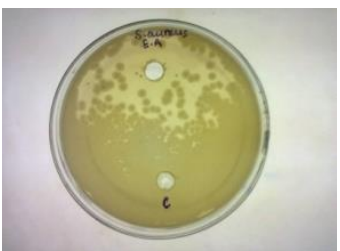

(c)

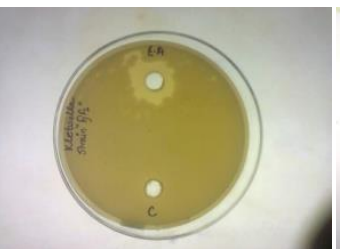

(d)

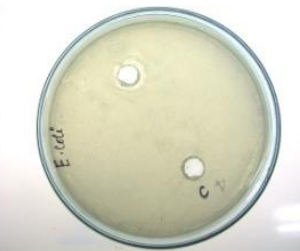

(e)

Figure 1 Antimicrobial activity of endophytic bacterial strain $\mathrm{FjF}_{2}$ against (a) Pseudomonas sp. (b) Proteus vulgaris (c) Staphylococcus aureus (d) Klebsiella sp. (e) Escherichia coli ; C- control (Ethyl acetate).

\section{Morphological, physiological and biochemical characterization}

According to morphological and biochemical characterization of all nineteen bacterial strains, they were found to be Gram positive. Gram positive $\mathrm{FjR}_{1}$ and $\mathrm{FjF}_{2}$ isolates exhibited positive results for endospore test and were found as the only isolates showing antimicrobial activity against all pathogenic bacteria tested. $\mathrm{FjR}_{1}$ and $\mathrm{FjF}_{2}$ were classified as Bacillus sp. according to their physiological, endospore and biochemical stests (Goryluk, 2009). $\mathrm{FjR}_{1}$ strain was able to grow in presence of $6 \% \mathrm{NaCl}, 0.1 \%$ phenol and $0.01 \%$ sodium azide. While $\mathrm{FjF}_{2}$ was found to be able to grow in the presence $8 \% \mathrm{NaCl}, 0.1 \%$ phenol and $0.15 \%$ sodium azide as depicted in Table 2. This shows that these two strains can even grow in such harsh conditions. Growth of $\mathrm{FjF}_{2}$ in presence of $0.15 \%$ sodium azide is noticeable although the growth was very less.

During biochemical characterization, $\mathrm{FjR}_{1}$ showed positive results for oxidase, nitrate reduction, gelatin liquefaction, starch hydrolysis, catalase and MR test while negative results for citrate utilization test. This strain was also found to produce L- asparaginase, an enzyme used in various types of cancer therapy. In contrast to the above strain, $\mathrm{FjF}_{2}$ showed positive result only for nitrate reduction and starch hydrolysis tests while negative results for all other tests (citrate utilization, oxidase, gelatin liquefaction, catalase and MR) performed. It did not produce L-asparaginase.

Carbohydrate fermentation tests were performed for all 19 isolates as shown in Table 3. During carbohydrate fermentation $\mathrm{FjR}_{1}$ was found to ferment fructose, xylose, maltose and raffinose but was not able to ferment lactose and sucrose sugars. $\mathrm{FjF}_{2}$ was able to ferment carbohydrates like lactose, sucrose, xylose and maltose but not fructose and raffinose.
Table 2-Physiological test of strain $\mathrm{FjR}_{1}$ and $\mathrm{FjF}_{2}$

\begin{tabular}{lcc}
\hline Effect of NaCl & $\mathbf{F j R}_{\mathbf{1}}$ & $\mathbf{F j F}_{\mathbf{2}}$ \\
\hline $2 \%$ & + & + \\
$4 \%$ & + & + \\
$6 \%$ & + & + \\
$8 \%$ & - & + \\
$10 \%$ & - & - \\
$12 \%$ & - & - \\
\hline Effect of Phenol & & \\
\hline $0.001 \%$ & + & + \\
$0.01 \%$ & + & + \\
$0.05 \%$ & + & + \\
$0.1 \%$ & + & + \\
$0.2 \%$ & - & - \\
$0.5 \%$ & - & - \\
\hline Effect of Sodium azide & & \\
\hline $0.001 \%$ & + & + \\
$0.01 \%$ & + & + \\
$0.05 \%$ & - & + \\
$0.1 \%$ & - & + \\
$0.15 \%$ & - & + \\
$0.2 \%$ & - & - \\
$0.5 \%$ & - & - \\
\hline+- positive, - - negative & &
\end{tabular}

Table 3 Biochemical characterization of bacterial endophytes

\begin{tabular}{|c|c|c|c|c|c|c|c|c|}
\hline $\begin{array}{l}\text { Bacterial } \\
\text { isolate }\end{array}$ & Citrate & Oxidase & Nitrate & Gelatin & Starch & Catalase & MR test & L-Asparaginase \\
\hline $\mathrm{FjR}_{1}$ & - & + & + & + & + & + & + & + \\
\hline $\mathrm{FjR}_{2}$ & - & + & + & + & - & + & + & + \\
\hline $\mathrm{FjL}_{1}$ & + & + & + & + & - & + & + & - \\
\hline $\mathrm{FjL}_{2}$ & - & + & + & - & - & - & + & - \\
\hline $\mathrm{FjL}_{3}$ & - & + & + & + & + & - & + & - \\
\hline $\mathrm{FjL}_{4}$ & - & - & + & + & - & - & + & - \\
\hline $\mathrm{FjS}_{1}$ & - & + & + & - & - & + & + & - \\
\hline $\mathrm{FjS}_{2}$ & - & + & + & - & - & - & + & - \\
\hline $\mathrm{FjS}_{3}$ & - & + & + & - & + & + & - & + \\
\hline $\mathrm{FjS}_{4}$ & - & + & + & - & + & + & + & + \\
\hline $\mathrm{FjB}$ & + & + & + & + & + & + & - & + \\
\hline $\mathrm{FjF}_{1}$ & - & + & + & - & - & - & + & - \\
\hline $\mathrm{FjF}_{2}$ & - & - & + & - & + & - & - & - \\
\hline $\mathrm{CrS}$ & - & + & + & + & + & + & - & - \\
\hline $\mathrm{CrL}$ & - & + & - & - & - & + & - & - \\
\hline $\mathrm{EoL}_{1}$ & - & + & + & - & + & + & - & - \\
\hline $\mathrm{EoL}_{2}$ & - & + & + & - & + & + & - & - \\
\hline $\mathrm{EoL}_{3}$ & - & + & + & & + & + & - & - \\
\hline EoS & - & + & + & + & - & + & - & - \\
\hline
\end{tabular}


Table 4 Carbohydrate fermentation test of isolated bacterial endophytes

\begin{tabular}{|c|c|c|c|c|c|c|}
\hline $\begin{array}{l}\text { Bacterial } \\
\text { isolate }\end{array}$ & Sucrose & Fructose & Lactose & xylose & Mannitol & Raffinose \\
\hline $\mathrm{FjR}_{1}$ & - & + & - & + & + & + \\
\hline $\mathrm{FjR}_{2}$ & - & + & - & + & - & + \\
\hline $\mathrm{FjL}_{1}$ & + & + & + & + & - & - \\
\hline $\mathrm{FjL}_{2}$ & + & - & + & + & - & - \\
\hline $\mathrm{FjL}_{3}$ & + & + & + & + & - & - \\
\hline $\mathrm{FjL}_{4}$ & + & - & + & - & - & - \\
\hline $\mathrm{FjS}_{1}$ & + & - & + & - & - & - \\
\hline $\mathrm{FjS}_{2}$ & + & + & + & - & + & + \\
\hline $\mathrm{FjS}_{3}$ & + & - & - & - & + & - \\
\hline $\mathrm{FjS}_{4}$ & + & - & - & - & + & - \\
\hline FjB & - & - & - & - & - & + \\
\hline $\mathrm{FjF}_{1}$ & - & + & - & + & + & + \\
\hline $\mathrm{FjF}_{2}$ & + & - & + & + & + & - \\
\hline $\mathrm{CrS}$ & + & + & + & - & - & - \\
\hline $\mathrm{CrL}$ & + & + & - & - & - & - \\
\hline $\mathrm{EoL}_{1}$ & - & + & + & - & + & + \\
\hline $\mathrm{EoL}_{2}$ & - & + & + & - & + & + \\
\hline $\mathrm{EoL}_{3}$ & - & + & + & - & + & + \\
\hline EoS & - & + & + & + & - & + \\
\hline
\end{tabular}

Antibiotic susceptibility test of pathogenic bacteria

In order to check the efficacy of antimicrobial activity of compounds produced by $\mathrm{FjR}_{1}$ and $\mathrm{FjF}_{2}$ isolates, a comparative study with respect to several known and available antibiotics was performed against pathogenic bacteria (Pseudomonas sp., Klebsiella sp., Proteus vulgaris, E.coli., S aureus) as shown in the Table-5, some pathogenic bacteria were found to have developed resistance against the known antibiotics used in the study. Only ciprofloxacin was found to be effective against all pathogenic bacteria used. Therefore, our finding is remarkable as compounds produced by $\mathrm{FjR}_{1}$ and $\mathrm{FjF}_{2}$ isolates are effective against all above pathogenic bacteria and hence may lead to development of highly effective antibiotics.

Table 5 Antibiotic susceptibility test of pathogenic bacteria through disc diffusion method

\begin{tabular}{|c|c|c|c|c|c|}
\hline $\begin{array}{l}\text { Antibiotics } \\
\text { disk } \\
\left(\mu \text { g.disk }^{-1}\right)\end{array}$ & S.aureus & E.coli & $\begin{array}{c}\text { Psudomonas } \\
\text { sp. }\end{array}$ & $\begin{array}{l}\text { Proteus } \\
\text { vulgaris }\end{array}$ & $\begin{array}{c}\text { Klebsiella } \\
\text { sp. }\end{array}$ \\
\hline $\mathrm{NF}(10 \mu \mathrm{g})$ & $\mathrm{R}$ & $\mathrm{S}$ & $\mathrm{S}$ & $\mathrm{S}$ & $\mathrm{S}$ \\
\hline $\mathrm{AT}(30 \mu \mathrm{g})$ & $\mathrm{S}$ & $\mathrm{R}$ & $\mathrm{R}$ & $\mathrm{R}$ & $\mathrm{R}$ \\
\hline $\mathrm{CX}(30 \mu \mathrm{g})$ & $\mathrm{S}$ & $\mathrm{S}$ & $\mathrm{R}$ & $\mathrm{R}$ & $\mathrm{R}$ \\
\hline FR $(30 \mu \mathrm{g})$ & $\mathrm{S}$ & $\mathrm{S}$ & $\mathrm{S}$ & $\mathrm{R}$ & $\mathrm{S}$ \\
\hline NA $(30 \mu \mathrm{g})$ & $\mathrm{R}$ & $\mathrm{R}$ & $\mathrm{S}$ & $\mathrm{S}$ & $\mathrm{R}$ \\
\hline FU $(300 \mu \mathrm{g})$ & $\mathrm{R}$ & $S$ & $\mathrm{~S}$ & $\mathrm{~S}$ & $\mathrm{~S}$ \\
\hline $\mathrm{CR}(30 \mu \mathrm{g})$ & $\mathrm{S}$ & $\mathrm{S}$ & $\mathrm{R}$ & $\mathrm{R}$ & $\mathrm{R}$ \\
\hline GM $(10 \mu \mathrm{g})$ & $\mathrm{R}$ & $\mathrm{S}$ & $\mathrm{S}$ & $\mathrm{S}$ & $\mathrm{S}$ \\
\hline $\mathrm{AK}(30 \mu \mathrm{g})$ & $\mathrm{R}$ & $\mathrm{S}$ & $\mathrm{S}$ & $\mathrm{S}$ & $\mathrm{S}$ \\
\hline $\mathrm{CI}(5 \mu \mathrm{g})$ & $\mathrm{S}$ & $\mathrm{S}$ & $\mathrm{S}$ & $\mathrm{S}$ & $\mathrm{S}$ \\
\hline $\mathrm{OF}(5 \mu \mathrm{g})$ & $\mathrm{R}$ & $\mathrm{S}$ & $\mathrm{S}$ & $\mathrm{S}$ & $\mathrm{S}$ \\
\hline $\mathrm{CZ}(30 \mu \mathrm{g})$ & $\mathrm{S}$ & $\mathrm{R}$ & $\mathrm{R}$ & $\mathrm{R}$ & $\mathrm{R}$ \\
\hline $\mathrm{FX}(5 \mu \mathrm{g})$ & $\mathrm{S}$ & $\mathrm{R}$ & $\mathrm{R}$ & $\mathrm{R}$ & $\mathrm{R}$ \\
\hline $\mathrm{CN}(5 \mu \mathrm{g})$ & $\mathrm{S}$ & $\mathrm{S}$ & $\mathrm{R}$ & $\mathrm{R}$ & $\mathrm{R}$ \\
\hline
\end{tabular}

NF- Norfloxacin, AT- Azetronam, CX- Cefotaxime, FR-Ceftriaxone, NA- Nalidixic acid, FU- Nitrofurantoin, CR- Cefuroxime, GM- Gentamycin, AK- Amikacin, CI- Ciprofloxacin OF- Ofloxacin, CZ-Ceftazidime, FX- Cefixime, CN- Cefdimr, R- Resistant, S- Sensitive

Some of the pathogenic microorganisms now a day become resistant to the effective antibiotics (Bisht $\boldsymbol{e t}$ al., 2009). Hence, discovery of novel and effective antibiotics are necessary (O'Donnell $\boldsymbol{e t} \boldsymbol{\text { al. }}$., 2010). In the recent time endophytes have emerged as novel source of antibiotics. In this study, endophytes from various parts of three different plants ( $F$. jangomas, E. officinalis and C. roseus) have been isolated. Till now there is no report about the isolation of endophytes from $F$. jangomas. This is for the first time endophytes showing antimicrobial activity are being reported from $F$. jangomas. This study evidenced that $F$. jangomas can be the potential but under exploited resources for endophytes. Bacterial endophytes isolated from $F$. jangomas have shown promising inhibition activity against pathogenic bacteria (both Gram positive and Gram negative) used in the study. Shibumon et al. (2010) reported about the isolation of 2, 3 Dihydroxy Benzoic acid as phenolic antimicrobial compound from acetonic fruit extract of Flacourtia inermis roxb which showed strong antimicrobial activity against multi drug resistant bacteria (Shibhumon and Benny, 2010). It could be possible that such antimicrobial activity in the plant extracts may be due to endophytes inhabiting in it. Further there is also report about the chloroform fraction prepared from roots of $F$. jangomas and $F$. separia showing strong antimicrobial activity against pathogenic bacteria (Sarker et al., 2011). Medicinal and endemic plants should be studied for endophytes as parts of these plants are expected to harbor rare and interesting endophytes for the production of natural and potential bioactive compounds (Strobel and Daisy, 2003).

\section{CONCLUSION}

As per our literature survey, antimicrobial compound from endophytic bacteria isolated from $F$. jangomas has not been earlier reported. A total of 13 isolates of bacterial endophytes were isolated from $F$. jangomas. Out of these, two isolates $\mathrm{FjF}_{2}$ and $\mathrm{FjR}_{1}$ showed broad spectrum of antimicrobial activity against both Gram positive and Gram negative pathogenic bacteria used in the study. While some pathogenic bacteria tested were found to have developed resistance against the known antibiotics used in the study except ciprofloxacin. There are several reports of antibiotics producing endophytes isolated from medicinal plants. Bacillus sp., B. licheniformis, Paenibacillus sp., B. pumilus and B. subtilis bacterial endophytes have been isolated from medicinal plants and are reported to produce antibiotics (Madigan et al., 2005). In another report, bacterial endophytes were isolated from different parts of Plectranthus tenuiflorus (medicinal plant in Saudi Arabia) and among all endophytes, Bacillus sp. exhibited the strong antimicrobial activity against human pathogenic bacteria tested (Staphylococcus aureus, Escherichia coli, Klebsiella pneumoniae, Streptococcus agalactiae, Proteus mirabilis and Candida albicans) (Deeb et al., 2012).

The bacterial endophytes isolated from $F$. jangomas (isolates $\mathrm{FjF}_{2}$ and $\mathrm{FjR}_{1}$ ) in this study have shown promising antimicrobial activity against human pathogenic bacteria. The further study may lead to the development of potential antibiotic drug which is the need of the day.

Acknowledgements: The authors are thankful to Department of Biotechnology, D.D.U Gorakhpur University, Gorakhpur for providing necessary facilities to carry out this work.

\section{REFERENCES}

ALY, A. H., DEBBAB, A., KJER, J., PROKSCH, P. 2010. Fungal endophytes from higher plants: A prolific source of phytochemicals and other biochemical natural products. Fungal diversity, 41, 1-16. http://dx.doi.org/10.1007/s13225010-0034-4

BACON, C. W., WHITE, J. F. 2000. Microbial endophytes. Marcel Dekker, New York.

BENNY, P.J., SHIBUMON, G., SUNNY, K., CINCY, G. 2010. 2, 3 Dihydroxybenzonic acid: An effective antifungal agent isolated from Flacourtia inermis fruit. Int. J. Pharma. Clin. Res., 2, 101-105.

BISHT, R., KATIYAR, A., SINGH, R., MITTAL, P. 2009. Antibiotic resistance - a global issue of concern. Asian J Pharm and Clin Res, 2, 34- 39. 
CAPPUCCINO, J. G., SHERMAN, N. 1998. Microbiology: a laboratory manual Sth edition. (Bernjamin Cummings: UK).

DEEB, B. E. L., FAYEZ, K., GHERBAWY, Y. 2012. Isolation and characterization of endophytic bacteria from Plectranthus tenuiflorus medicinal plant in Saudi Arabia desert and their antimicrobial activities. Journal of Plant Interactions, 1-9. http://dx.doi.org/10.1080/17429145.2012.680077

EL-MEHALAWY, A., A., ABD-ALLAH, N., A., MOHAMED, R., M., ABUSHAY, M., R. 2005. Actinomycetes antagonizing plant and human pathogenic fungi II. Factors affecting antifungal production and chemical characterization of the active components. Int J Agric Biol, 7(2), 188-196.

GORYLUK, A., REKSOZ-BURLAG, H., BLASZCYK, M. 2009. Isolation and Characterization of bacterial endophytes of Chelidonium majus L. Polish Journal of Microbiology, 58, 355-361.

HALLMANN, J., QUADT-HALLMANN, A., MAHAFFEE, W. F., KLOEPPER, J. W. 1997. Bacterial endophytes in agricultural crops. Canadian Journal of Microbiology, 43, 895-914. http://dx.doi.org/10.1139m97-131

HUNG, P. Q., ANNAPURNA, K. 2004. Isolation and characterization of endophytic bacteria in soybean (Glycine sp.). Omonrice, 12, 92-101.

KHAN, A. V., AHMED Q. U., MIR M. R., SHUKLA, I., KHAN A., A. 2011. Antibacterial efficacy of the seed extracts of Melia azedarach against some hospital isolated human pathogenic bacterial strains. Asian Pacific Journal of Tropical Biomedicine, 452-455. http://dx.doi.org/10.1016/s2221. 1691(11)60099-3

KORZYBSKI, T., KOWSZYK-GIFINDER, Z., KURYTOWICZ, W. 1978. Antibiotics: origin, nature, and properties. Washington, D.C.: American Society for Microbiology.

LIMA, A. O. S., QUECINE, M. C., FUNGARO, M. H. P., ANDREOTE, F. D. MACCHERONI, J. R. W., ARAÚJO, W., L. 2005. Molecular characterization of a B-1,4-endoglucanase from an endophytic Bacillus pumilus strain. Applied Microbiology and Biotechnology, 68, 57-65. http://dx.doi.org/10.1007/s00253004-1740-1

MADIGAN, M., MARTINKO, J., PARKER, J. 2005. Biology of microorganisms. Brock; New York, NY: Prentice Hall, 1088 p.

O'DONNELL, F., SMYTH, T., J., P., RAMACHANDRAN, V., N., SMYTH, W., F. 2010. A study of the antimicrobial activity of selected synthetic and naturally occurring quinolines. Int $J$ Antimicrob Agent., 35, 30-38, http://dx.doi.org/10.1016/j.ijantimicag.2009.06.031

OSKAY, M., TAMER, A., U., AZERI, C. 2004. Antibacterial activity of some actinomycetes isolated from farming soils of Turkey. African journal of biotechnology, 3(9), 441-446.

PANDEY, B., GHIMIRE, P., AGRAWAL, V., P. 2004. Studies on antibacterial activity of the actinomycetes isolated from the Khumbu region of Nepal. J. Bio. Sci., 23, 44-53.

PLEBAN, S., CHERNIN, L., CHET, I. 1997. Chitinolytic activity of an endophytic strain of Bacillus cereus. Letters in Applied Microbiology, 25, 284288. http://dx.doi.org/10.1046/j.1472-765x.1997.00224.X

ROSENBLUETH, M., E., MARTINES-ROMERO. 2006. Bacterial endophytes

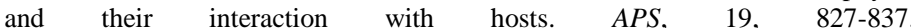
http://dx.doi.org/10.1094/mpmi-19-0827

RYAN, R., P., GERMAINE, K., FRANKS, A., RYAN, D., J., DOWLING, D., N. 2008. Bacterial endophytes: Recent developments and applications. FEMS Microbiol. Lett, 278, 1-9. http://dx.doi.org/10.1111/j.1574-6968.2007.00918.x

SARKER, G., C., ZOHAN, R., ALAM, M., B., ISLAM, M., D., S., MOSADDIK, M., A., HAQUE, KARAMUL, M., E. 2011. Antibacterial activity of Flacourtia jangomas and Flacourtia sepiaria. Int. J. of Pharm. \& Life sci., 2 878-883.

SHIBUMON, G., BENNY, P., J. 2010. Antibacterial potency of fruit extracts of Flacourtia inermis against multidrug resistant strains and comparison of its activity with that of standard antibiotics. Int J pharm Sci, 1(2), 96-99.

SINGH, N., KUMAR, R., KHATAK, S., MALIK, D., K., GREWAL, A. 2013. Morphological, physiological and biochemical characterization of bacteria isolated from pineapple juice. Asian J. Exp. Biol. Sci., 4(4), 651-653.

SRIVASTAVA, D., SHEIKH, S., PRABHUJI, S., K., RAO, G., P., TRIPATHI, $\begin{array}{lll}\text { A., } & \text { SRIBASTAVA, } & \text { R. } 2012 . \\ \text { In vitro antibacterial activities }\end{array}$ of Flacourtia jungomas (Lour.) Raeus. fruit extracts Medicinal PlantsInternational journal of phytomedicines and related industries, 4(2), 98-100. http://dx.doi.org/10.5958/j.0975-4261.4.2.008

STIERLE, A., STROBEL, G., STIERLE, D. 1993. Taxol and taxane production by Taxomyces andreanae, an endophytic fungus of Pacific yew. Science, 260 , 214-216. http://dx.doi.org/10.1126/science.8097061

STROBEL, G. A., DAISY, B. 2003. Bioprospecting for microbial endophytes and their natural products. Microbiol Mol Biol Rev, 67, 491-502. http://dx.doi.org/10.1128/mmbr.67.4.491-502.2003

STROBEL, G., DAISY, B., CASTILLO, U., HARPER, J. 2004. Natural products from endophytic microorganisms. $J$ Nat Prod, 67, 257-268. http://dx.doi.org/10.1021/np030397y

TRISCHMAN, J., A., TAPIOLAS, D., M., JENSEN, P., R., DWIGHT, R., FENICAL, W., MCKEE, T., C. 1994. Salinamide-A and salinamide-B: antiinflammatory depsipeptides from a marine Streptomycete. American Chemical Society, 116, 757-758. http://dx.doi.org/10.1021/ia00081a042
WILSON, D. 1995. Endophytes- The evolution of the term and clarification of its use and definition. Oikos, 73, 274-276. http://dx.doi.org/10.2307/3545919 